\title{
SOME EFFECTS OF TEMPERATURE ON THE SHOOT GROWTH OF CHERRY SEEDLINGS
}

\author{
L. SMEETS \\ Institute of Horticultural Plant Breeding, Wageningen, Netherlands \\ Received 23 Febr. 1957
}

\section{INTRODUCTION}

For cherry breeding it is important to know the factors governing the growth and development of cherry seedlings (4). To this end experiments on the influence of the photoperiod were started in the phytotron of our Institute. Some of the results have been published in a previous paper (7). It was found that in a number of first-year seedlings the duration of growth was affected by the photoperiod, whereas this was not the case in second-year seedlings.

However, growth is affected not only by the light conditions, but also by temperature. Therefore some experiments on the influence of temperature on the growth of cherry seedlings were carried out. Since it is known from the literature $(2,3,8)$ that an alternation of temperatures within a 24 hour's cycle may increase growth significantly, compared with the growth of plants kept at constant temperatures, the effect of both day and night temperature was studied. In this paper the results obtained so far will be reported and discussed.

\section{MATERIAL AND METHODS}

First- and second-year seedlings of Limburgse Boskriek (Prunus avium L.) were used as test plants. They were grown from seed supplied by the Netherlands Inspection Service for Arboriculture (N.A.K.-B).

The experiments were carried out in air-conditioned glasshouses in the phytotron of our Institute. Details of the equipment have been published in a previous issue of this periodical (1).

The effect of both day and night temperature on shoot growth under natural daylength conditions was studied. The plants, which were placed on trolleys, were either grown at various constant temperatures during the day and night or at the same temperatures by day (from 8 a.m. till 4 p.m.) but at lower temperatures at night. In general the maximum deviation from the mean temperature was about $1^{\circ} \mathrm{C}$. Only on exceptionally hot days did the temperature rise in the $20^{\circ} \mathrm{C}$ glasshouse to about $25^{\circ} \mathrm{C}$ in the afternoon (1).

The height of the plants was measured at intervals from the beginning of the experiments until the termination of shoot growth. At the same time the number of leaves was counted. Keuls' application of the "studentized range" method (5) was used to find out what temperature treatments resulted in mathematically reliable differences in shoot length and leaf number. 


\section{EXPERIMENTAL RESULTS}

In the first experiment, seedlings of Limburgse Boskriek in their first year of growth were used as test plants. They were grown from seed stratified from September 30 until December 29, 1953; then the seeds were sown in seed-trays and placed in a coldhouse. The young seedlings were pricked off in pots on April 2, 1954. The plants were divided into 10 groups on April 27 and grown one at each of the temperature treatments shown in table 1.

All groups of plants consisted of 20 plants except those grown at a day temperature of $23^{\circ} \mathrm{C}$ and a night temperature of $20^{\circ}$ or $17^{\circ} \mathrm{C}$, which consisted of 19 plants each. About 20 plants per treatment agrees with a recommendation of NEUMANN (6) based upon a coefficient of variation of the same magnitude as those found in the present experiments.

Table 1 shows that the plants grown at constant temperatures of $17^{\circ}$ and $20^{\circ} \mathrm{C}$ terminated their growth much sooner than those grown at $23^{\circ}$ and $26^{\circ} \mathrm{C}$. At $20^{\circ} \mathrm{C}$ the majority of the plants seemed to cease growth somewhat earlier than at $17^{\circ} \mathrm{C}$, whereas at $26^{\circ} \mathrm{C}$ termination of shoot growth occurred markedly later than at $23^{\circ} \mathrm{C}$.

TABle 1. Influence OF THE TEMPERATURE ON THE TERMination OF SHOOT GROWTH IN FiRST-YeaR SEEDLINGS OF LIMBURGSE BOSKRIEK (PRUNUS AVIUM L.)

\begin{tabular}{|c|c|c|c|c|c|c|c|c|c|c|c|}
\hline \multicolumn{2}{|c|}{$\begin{array}{l}\text { Temperatures } \\
\text { (degrees C) }\end{array}$} & \multicolumn{10}{|c|}{$\begin{array}{l}\text { Total number of plants which had terminated growth on the date } \\
\text { mentioned at the head of each column }\end{array}$} \\
\hline Day & Night & $14 / 6$ & $22 / 6$ & $30 / 6$ & $7 / 7$ & $16 / 7$ & $26 / 7$ & $9 / 8$ & $16 / 8$ & $23 / 9$ & $20 / 10$ \\
\hline 17 & 17 & 1 & 3 & 7 & 13 & 19 & 20 & & & & \\
\hline 20 & 17 & - & 3 & 9 & 13 & 19 & 20 & & & & \\
\hline 20 & 20 & 1 & 9 & 13 & 16 & 19 & 19 & 20 & & & \\
\hline 23 & 17 & - & 1 & 4 & 8 & 12 & 17 & 17 & 17 & 18 & 19 \\
\hline 23 & 20 & - & 2 & 6 & 9 & 12 & 16 & 18 & 18 & 18 & 19 \\
\hline 23 & 23 & - & 2 & 3 & 10 & 11 & 14 & 15 & 17 & 19 & 20 \\
\hline 26 & 17 & 1 & 2 & 5 & 6 & 10 & 13 & 18 & 20 & & \\
\hline 26 & 20 & 1 & 4 & 5 & 12 & 15 & 16 & 16 & 18 & 20 & \\
\hline 26 & 23 & - & - & 2 & 3 & 8 & 15 & 16 & 16 & 18 & 20 \\
\hline 26 & 26 & - & - & - & 2 & 3 & 8 & 10 & 14 & 17 & 20 \\
\hline
\end{tabular}

The night temperature had a distinct effect only on plants grown at a day temperature of $26^{\circ} \mathrm{C}$. At night temperatures of $23^{\circ}, 20^{\circ}$ and $17^{\circ} \mathrm{C}$, the majority of the plants ceased growth earlier than those grown at $26^{\circ} \mathrm{C}$ during the day and night. However at a night temperature of $20^{\circ} \mathrm{C}$ termination of shoot growth occurred earlier than at $23^{\circ} \mathrm{C}$, while there was no difference in this respect between the plants grown at night temperatures of $20^{\circ}$ and $17^{\circ} \mathrm{C}$. There was no effect of the night temperature on the plants grown at a day temperature of $23^{\circ} \mathrm{C}$. In the plants grown at a day temperature of $20^{\circ} \mathrm{C}$ and a night temperature of $17^{\circ} \mathrm{C}$ termination of shoot growth occurred somewhat later than in those grown at a constant temperature of $20^{\circ} \mathrm{C}$.

Table 2 shows the average shoot length and number of leaves at the different temperatures on June 8, 1954, and after termination of growth. The results of the statistical analysis of these data are presented in table 3. 


\section{SHOOT GROWTH OF CHERRY SEEDLINGS}

TABLE 2. INFLUENCE OF THE TEMPERATURE ON GROWTH OF FIRST-YEAR SEEDLINGS OF LIMBURGSE BOSKRIEK (PRUNUS AVIUM L.)

\begin{tabular}{l|c|c|c|c|c}
\hline \multicolumn{2}{c|}{$\begin{array}{c}\text { Temperatures } \\
\text { (degrees C) }\end{array}$} & \multicolumn{2}{c}{ June 8, 1954 } & \multicolumn{2}{c}{ After termination of growth } \\
\hline Day & Night & $\begin{array}{c}\text { Average shoot } \\
\text { length (cm) }\end{array}$ & $\begin{array}{c}\text { Average number } \\
\text { of leaves }\end{array}$ & $\begin{array}{c}\text { Average shoot } \\
\text { length (cm) }\end{array}$ & $\begin{array}{c}\text { Average number } \\
\text { of leaves }\end{array}$ \\
\hline & & & & & \\
17 & 17 & 31.5 & 12.7 & 46.8 & 18.0 \\
20 & 17 & 38.1 & 13.9 & 56.4 & 19.1 \\
20 & 20 & 42.7 & 15.2 & 59.5 & 20.6 \\
23 & 17 & 42.2 & 14.8 & 78.2 & 24.7 \\
23 & 20 & 43.5 & 15.3 & 66.4 & 24.2 \\
23 & 23 & 41.2 & 15.3 & 80.4 & 27.7 \\
26 & 17 & 49.3 & 15.9 & 78.3 & 25.0 \\
26 & 20 & 51.9 & 17.9 & 76.5 & 27.0 \\
26 & 23 & 42.8 & 16.5 & 76.4 & 28.8 \\
26 & 26 & 48.3 & 17.9 & 100.0 & 37.1 \\
\end{tabular}

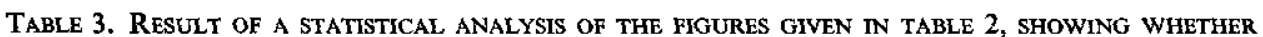
THE DIFFERENCES IN SHOOT LENGTH AND LEAF NUMBER BETWEEN THE TEMPERATURE TREATMENTS IN THE HEADINGS AND THOSE IN THE FIRST COLUMN ARE SIGNIFICANTLY POSITIVE $(+)$, OR NEGATIVE $(-)$, ON A $1 \%$ LEVEL

\begin{tabular}{|c|c|c|c|c|c|c|c|c|c|c|c|c|c|c|c|c|c|}
\hline \multirow{2}{*}{\multicolumn{2}{|c|}{$\begin{array}{l}\text { Temperatures } \\
\text { (degrees C) }\end{array}$}} & \multicolumn{8}{|c|}{ June 8, 1954} & \multicolumn{8}{|c|}{ After termination of growth } \\
\hline & & \multicolumn{4}{|c|}{$\begin{array}{l}\text { Average shoot } \\
\text { length }(\mathrm{cm})\end{array}$} & \multicolumn{4}{|c|}{$\begin{array}{c}\text { Average number } \\
\text { of leaves }\end{array}$} & \multicolumn{4}{|c|}{$\begin{array}{l}\text { Average shoot } \\
\text { length }(\mathrm{cm})\end{array}$} & \multicolumn{4}{|c|}{$\begin{array}{c}\text { Average number } \\
\text { of leaves }\end{array}$} \\
\hline Day & Night & $\begin{array}{l}17 \\
17\end{array}$ & $\begin{array}{l}20 \\
20\end{array}$ & $\begin{array}{l}23 \\
23\end{array}$ & $\begin{array}{l}26 \\
26\end{array}$ & $\begin{array}{l}17 \\
17\end{array}$ & $\begin{array}{l}20 \\
20\end{array}$ & $\begin{array}{l}23 \\
23\end{array}$ & $\begin{array}{l}26 \\
26\end{array}$ & $\begin{array}{l}17 \\
17\end{array}$ & $\begin{array}{l}20 \\
20\end{array}$ & $\begin{array}{l}23 \\
23\end{array}$ & $\begin{array}{l}26 \\
26\end{array}$ & $\begin{array}{l}17 \\
17\end{array}$ & $\begin{array}{l}20 \\
20\end{array}$ & $\begin{array}{l}23 \\
23\end{array}$ & $\begin{array}{l}26 \\
26\end{array}$ \\
\hline $\begin{array}{l}17 \\
20 \\
20 \\
23 \\
23 \\
23 \\
26 \\
26 \\
26 \\
26\end{array}$ & $\begin{array}{l}17 \\
17 \\
20 \\
17 \\
20 \\
23 \\
17 \\
20 \\
23 \\
26\end{array}$ & $\begin{array}{l}- \\
- \\
- \\
- \\
- \\
- \\
- \\
-\end{array}$ & + & + & + & $\begin{array}{l}- \\
- \\
- \\
- \\
- \\
- \\
- \\
-\end{array}$ & + & + & $\begin{array}{l}+ \\
+ \\
+ \\
+ \\
+ \\
+\end{array}$ & $\begin{array}{l}- \\
- \\
- \\
- \\
- \\
- \\
-\end{array}$ & - & $\begin{array}{l}+ \\
+ \\
+\end{array}$ & $\begin{array}{l}+ \\
+ \\
+ \\
+ \\
+ \\
+ \\
+ \\
+ \\
+\end{array}$ & $\begin{array}{l}- \\
- \\
- \\
- \\
- \\
- \\
-\end{array}$ & $\begin{array}{l}- \\
- \\
-\end{array}$ & $\begin{array}{l}+ \\
+ \\
+\end{array}$ & $\begin{array}{l}+ \\
+ \\
+ \\
+ \\
+ \\
+ \\
+ \\
+ \\
+\end{array}$ \\
\hline
\end{tabular}

Let us consider first the differences in shoot length and leaf number after termination of growth. It appears that the plants grown at a constant temperature of $26^{\circ} \mathrm{C}$ differed significantly from all others both in shoot length and leaf number. The plants grown at $23^{\circ} \mathrm{C}$ during the day and night also differed in this respect from those grown at lower day temperatures (see also Fig. 1). So significant differences in both shoot length and leaf number appear to occur only in those cases in which the duration of growth is affected either by the day or night temperature (cf. Tables 2 and 3 with Table 1). Now it might be questioned whether these differences were only due to differences in the duration of growth or whether they were also affected by the rate of growth. From table 3 it appears that on June 8, 1954, i.e. before any effect of temperature on the 

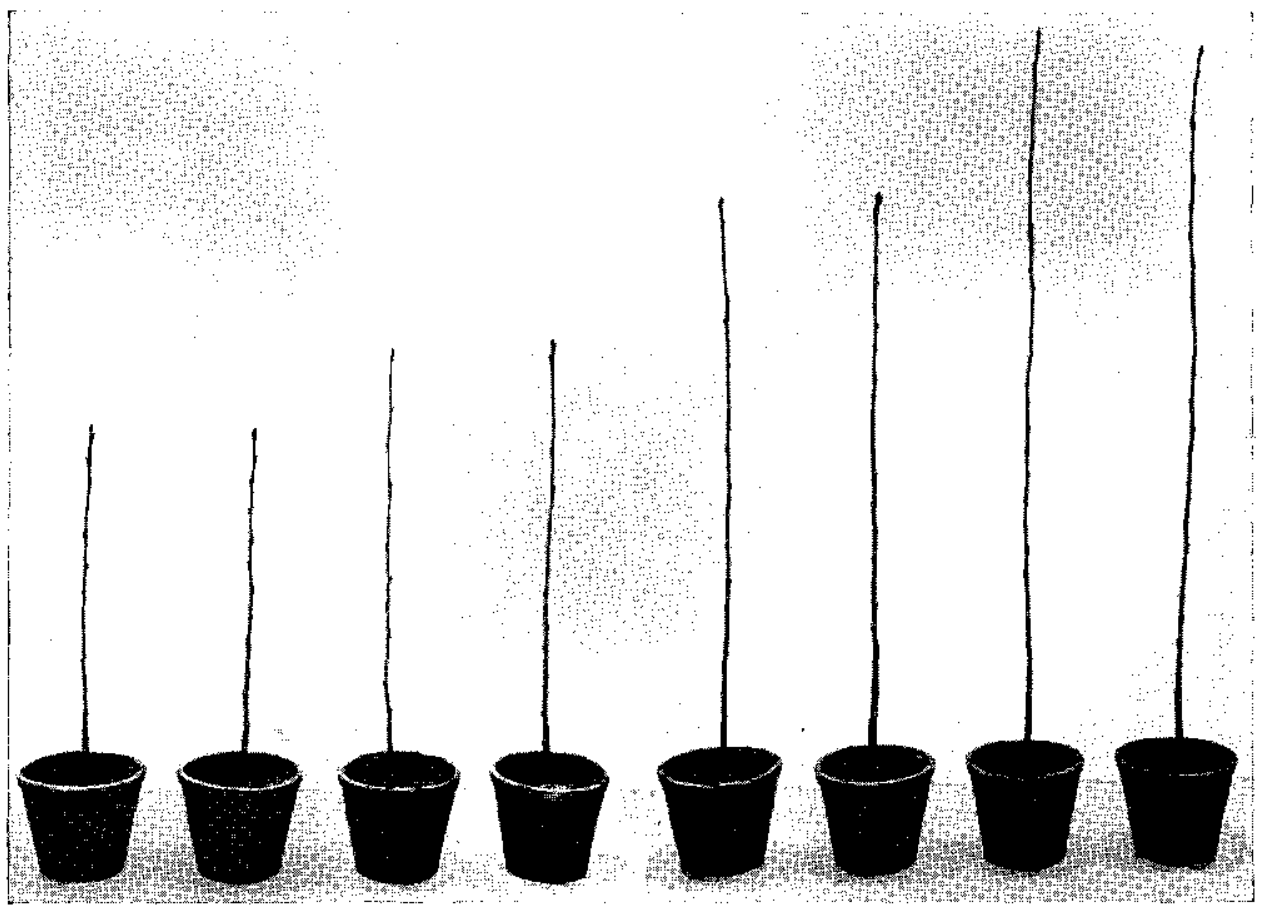

FIG. 1 FROM LEFT TO RIGHT, PAIRS OF FIRST-YEAR SEEDLINGS OF LIMBURGSE BOSKRIEK (PRUNUS AVIUM L.), GROWN AT CONSTANT TEMPERATURES OF $17^{\circ}, 20^{\circ}, 23^{\circ}$ AND $26^{\circ} \mathrm{C}$ RESPECTIVELY, SHOWING THE AVERAGE PLANT HEIGHT AFTER TERMINATION OF GROWTH. THE PHOTOGRAPH WAS TAKEN WHEN THE PLANTS HAD DROPPED THEIR LEAVES DUE TO A COLD TREATMENT AFTER TERMINATION OF GROWTH.

duration of growth was noticeable, there were already significant differences both in shoot length and leaf number between the plants grown at constant temperatures of $26^{\circ}$ and $23^{\circ}$ on the one hand and $17^{\circ} \mathrm{C}$ on the other, which means a higher rate of growth in the former case than in the latter. Although in some cases the final differences in shoot length and leaf number between the temperature treatments mentioned above are affected by the rate of growth, it appears that they are mainly due to the effect of temperature on the duration of growth.

On June 8, 1954, there were no differences in shoot length and number of leaves between the plants grown at different night temperatures but at the same day temperature. This was also the case after termination of growth except for the plants grown at a constant temperature of $26^{\circ} \mathrm{C}$, which differed significantly both in shoot length and leaf number from those grown at the same temperature by day but at lower temperatures at night, obviously as a result of differences in the duration of growth. Consequently, within the range of temperatures studied in this experiment, there was no effect of the night temperature on the rate of growth of the plants.

At the end of this experiment the plants were transferred to a coldhouse in order to bring about leaf-abscission and break the dormancy of the buds. Early in February 1955 


\section{SHOOT GROWTH OF CHERRY SEEDLINGS}

the plants, which had been cut back to a height of about $10 \mathrm{~cm}$, were placed at a constant temperature of $20^{\circ} \mathrm{C}$ for bud break. Only one shoot from the developing buds of each plant was retained.

On February 25, 1955, the plants were divided into 6 groups of 20 plants, in such a way that the plants of the first year groups were equally distributed among the groups of the second year. A statistical analysis showed that in this way the effect of the positive correlation between the final height of the individual plants in their first and second year of growth was eliminated. Three groups were grown one at each of the constant temperatures $17^{\circ}, 20^{\circ}$ and $23^{\circ} \mathrm{C}$. Two groups were grown at a day temperature of $23^{\circ}$ and at a night temperature of $20^{\circ}$ and $17^{\circ} \mathrm{C}$ respectively. One group was grown at a day temperature of $20^{\circ} \mathrm{C}$ and a night temperature of $17^{\circ} \mathrm{C}$.

Table 4 shows that growth was terminated much sooner at constant temperatures of $17^{\circ}$ and $20^{\circ}$ than at $23^{\circ} \mathrm{C}$, whereas most of the plants at $20^{\circ} \mathrm{C}$ ceased growth sooner than at $17^{\circ} \mathrm{C}$.

TABLE 4. INFLUENCE OF THE TEMPERATURE ON THE TERMINATION OF SHOOT GROWTH IN SECOND-YEAR SEEDLINGS OF LIMBURGSE BOSKRIEK (PRUNUS AVIUM L.)

\begin{tabular}{|c|c|c|c|c|c|c|c|c|c|c|c|}
\hline \multicolumn{2}{|c|}{$\begin{array}{l}\text { Temperatures } \\
\text { (degrees } \mathrm{C} \text { ) }\end{array}$} & \multicolumn{10}{|c|}{$\begin{array}{l}\text { Total number of plants which had terminated growth on the date } \\
\text { mentioned at the head of each column }\end{array}$} \\
\hline Day & Night & $6 / 4$ & $14 / 4$ & $21 / 4$ & $28 / 4$ & $6 / 5$ & $13 / 5$ & $20 / 5$ & $27 / 5$ & $3 / 6$ & $20 / 6$ \\
\hline 17 & 17 & 2 & 5 & 8 & 17 & 19 & 19 & 19 & 19 & 20 & \\
\hline 20 & 17 & 4 & 9 & 14 & 20 & & & & & & \\
\hline 20 & 20 & 5 & 10 & 18 & 19 & 20 & & & & & \\
\hline 23 & 17 & 5 & 10 & 14 & 17 & 19 & 20 & & & & \\
\hline 23 & 20 & 1 & 8 & 15 & 17 & 18 & 19 & 19 & 19 & 19 & 20 \\
\hline 23 & 23 & 3 & 3 & 3 & 3 & 3 & 4 & 6 & 14 & 18 & 20 \\
\hline
\end{tabular}

The night temperature had a distinct effect on the plants grown at a day temperature of $23^{\circ} \mathrm{C}$. At night temperatures of $20^{\circ}$ and $17^{\circ} \mathrm{C}$ the majority of the plants terminated their growth much sooner than those grown at $23^{\circ} \mathrm{C}$ during the day and night. There was no effect of the night temperature on the plants grown at a day temperature of $20^{\circ} \mathrm{C}$.

Table 5 shows the average shoot length and number of leaves at the different temperatures both after termination of growth and on March 22, 1955, i.e. before any effect of temperature on the duration of growth was noticeable. The results of the statistical analysis of these data are presented in table 6 .

As the results were similar to those obtained in the experiment with first-year seedlings it will suffice to mention only the conclusions that may be drawn from tables 5 and 6. It appears that significant differences occurring simultaneously in shoot length and leaf number after termination of growth were mainly due to the effect of temperature on the duration of growth. Within the temperature range studied no effect of the night temperature on the growth rate of the plants was observed. 


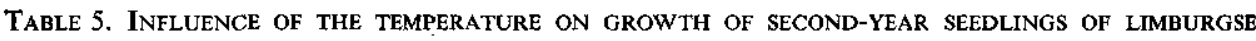
BOSKRIEK (PRUNUS AVIUM L.)

\begin{tabular}{c|c|c|c|c|c}
\hline \multicolumn{2}{c|}{$\begin{array}{c}\text { Temperatures } \\
\text { (degrees C) }\end{array}$} & \multicolumn{2}{|c|}{ March 22, 1955 } & \multicolumn{2}{c}{ After termination of growth } \\
\hline Day & Night & $\begin{array}{c}\text { Average shoot } \\
\text { length (cm) }\end{array}$ & $\begin{array}{c}\text { Average number } \\
\text { of leaves }\end{array}$ & $\begin{array}{c}\text { Average shoot } \\
\text { length (cm) }\end{array}$ & $\begin{array}{c}\text { Average number } \\
\text { of leaves }\end{array}$ \\
\hline & & & & & \\
17 & 17 & 63.0 & 16.9 & 104.0 & 27.3 \\
20 & 17 & 63.4 & 17.6 & 91.7 & 25.4 \\
20 & 20 & 69.5 & 18.5 & 95.3 & 26.4 \\
23 & 17 & 69.1 & 18.9 & 99.0 & 26.9 \\
23 & 20 & 73.8 & 20.2 & 105.6 & 30.0 \\
23 & 23 & 75.3 & 20.6 & 142.0 & 39.0
\end{tabular}

TABLE 6. ResUlt OF A STATISTICAL ANALYSIS OF THE FIGURES Given IN TABLE 5 , SHOWING WHETHER THE DIFFERENCES IN SHOOT LENGTH AND LEAF NUMBER BETWEEN THE TEMPERATURE TREATMENTS IN THE HEADINGS AND THOSE IN THE FIRST COLUMN ARE SIGNIFICANTLY POSITIVE $(+)$, oR NEGATIVE (-), ON A $1 \%$ LEVEL

\begin{tabular}{|c|c|c|c|c|c|c|c|c|c|c|c|c|c|}
\hline \multirow{2}{*}{\multicolumn{2}{|c|}{$\begin{array}{c}\text { Temperatures } \\
\text { (degrees C) }\end{array}$}} & \multicolumn{6}{|c|}{ March 22, 1955} & \multicolumn{6}{|c|}{ After termination of growth } \\
\hline & & \multicolumn{3}{|c|}{$\begin{array}{l}\text { Average shoot } \\
\text { length }(\mathrm{cm})\end{array}$} & \multicolumn{3}{|c|}{$\begin{array}{l}\text { Average number } \\
\text { of leaves }\end{array}$} & \multicolumn{3}{|c|}{$\begin{array}{l}\text { Average shoot } \\
\text { length }(\mathrm{cm})\end{array}$} & \multicolumn{3}{|c|}{$\begin{array}{c}\text { Average number } \\
\text { of leaves }\end{array}$} \\
\hline Day & Night & $\begin{array}{l}17 \\
17\end{array}$ & $\begin{array}{l}20 \\
20\end{array}$ & $\begin{array}{l}23 \\
23\end{array}$ & $\begin{array}{l}17 \\
17\end{array}$ & $\begin{array}{l}20 \\
20\end{array}$ & $\begin{array}{l}23 \\
23\end{array}$ & $\begin{array}{l}17 \\
17\end{array}$ & $\begin{array}{l}20 \\
20\end{array}$ & $\begin{array}{l}23 \\
23\end{array}$ & $\begin{array}{l}17 \\
17\end{array}$ & $\begin{array}{l}20 \\
20\end{array}$ & $\begin{array}{l}23 \\
23\end{array}$ \\
\hline $\begin{array}{l}17 \\
20 \\
20 \\
23 \\
23 \\
23\end{array}$ & $\begin{array}{l}17 \\
17 \\
20 \\
17 \\
20 \\
23\end{array}$ & $\begin{array}{l}- \\
-\end{array}$ & & $\begin{array}{l}+ \\
+\end{array}$ & $\begin{array}{l}- \\
-\end{array}$ & & $\begin{array}{l}+ \\
+\end{array}$ & - & - & $\begin{array}{l}+ \\
+ \\
+ \\
+ \\
+\end{array}$ & - & - & $\begin{array}{l}+ \\
+ \\
+ \\
+ \\
+\end{array}$ \\
\hline
\end{tabular}

\section{Discussion}

In the previous section it was shown that first- and second-year seedlings terminated their growth much sooner at $17^{\circ}$ and $20^{\circ} \mathrm{C}$ than at $23^{\circ} \mathrm{C}$. There was not much difference between the effect of $17^{\circ}$ and $20^{\circ} \mathrm{C}$; probably termination of growth occurred somewhat earlier at the latter temperature.

The difference in the duration of growth between $20^{\circ}$ and $23^{\circ} \mathrm{C}$ was greater in second- than in first-year seedlings. Apparently this accounts for the fact that only in second-year seedlings did the night temperature affect the duration of growth of plants grown at a day temperature of $23^{\circ} \mathrm{C}$.

The difference in the duration of growth mentioned above might be due to differences in response between the seedlings in their first and second year of growth. However, the experiment with second-year seedlings was started earlier than that with first-year seedlings. Therefore it is also possible that differences in the light conditions may have had an effect.

In this connection, it is of interest to compare the influence of the natural daylength 
on the $20^{\circ} \mathrm{C}$ series with the effect of 8- and 16-hr. photoperiods on first- and secondyear seedlings grown in previous experiments at a constant temperature of $20^{\circ} \mathrm{C} \mathrm{(6).}$ In these experiments the plants received every day 8 hours daylight from 8 a.m. till 4 p.m.; after transference to air-conditioned rooms, they were either placed in darkness or received 8 hours additional incandescent light of low intensity. It was found that distinct differences in the duration of growth between the plants grown under 8-and 16-hr. photoperiods only occurred in first-year seedlings. In the present experiments, however, there were no distinct differences in the duration of growth between the seedlings in their first and second year of growth when grown at a constant temperature of $20^{\circ} \mathrm{C}$. Apparently the variation in the duration of growth in first-year seedlings under long days is affected by the light conditions.

Finally it should be noted that in the Earhart Laboratory the effect of both day and night temperature on the growth of tomato, Chili pepper and tobacco has been studied extensively $(2,3,8)$. It was found that at first the rate of growth of the stem was highest at fairly high constant temperatures. As the plants became taller, however, the optimal night temperature shifted to a lower temperature, resulting in a more rapid growth at alternating than at constant temperatures. However, within the temperature range studied in the experiments reported in this paper, no effect of the night temperature on the growth rate of the plants was observed.

\section{SUMMARY}

In the phytotron of our Institute the effect was studied of different day and night temperatures on the shoot growth of first- and second-year seedlings of Limburgse Boskriek (Prunus avium L.) grown under natural daylength conditions.

It was found that, after termination of growth, significant differences occurring simultaneously in shoot length and leaf number between the temperature treatments were mainly due to the effect of the day or night temperature on the duration of growth. In some cases these differences were also influenced by the effect of temperature on the rate of growth. Within the range of temperatures studied, no effect of the night temperature on the rate of growth was observed.

\section{SAMENVATTING}

\section{Invloed van de temperatuur op de scheutgroei van kersezaailingen}

In het fytotron van ons Instituut werd de invloed bestudeerd van verschillende dagen nachttemperaturen op de scheutgroei van zaailingen van Limburgse Boskriek (Prunus avium L.) in hun le en 2 e groeijaar onder een natuurlijke daglengte.

Gebleken is dat, na het afsluiten van de groei, betrouwbare gelijktijdig voorkomende verschillen zowel in scheutlengte als aantal bladeren tussen de temperatuurbehandelingen in hoofdzaak het gevolg zijn van de invloed van de dag- of nachttemperatuur op de duur van de groei. In enkele gevallen werden deze verschillen ook beïnvloed door het effect van de temperatuur op de groeisnelheid. In het onderzochte temperatuurgebied werd geen invloed waargenomen van de nachttemperatuur op de groeisnelheid. 


\section{SMEETS}

\section{LITERATURE CITED}

1. BRAAK, J. P. and SmeErs, L., The phytotron of the Institute of Horticultural Plant Breeding at Wageningen, Netherlands. Euphytica 5 (1956): 205-217.

2. Camus, G. C., and WeNT, F. W., The thermoperiodicity of three varieties of Nicotiana tabacum. Amer. Journ. Bot. 39 (1952): 521-528.

3. DoRland, R. E., and WENT, F. W., Plant growth under controlled conditions. VIII. Growth and fruiting of the Chili pepper (Capsicum annuum). Amer. Journ. Bot. 34 (1947): 393-401.

4. GeRRITSEN, C. J., Improvement of the cherry varieties grown in the Netherlands. Euphytica 5 (1956): 101-116.

5. Keuss, M., The use of the "studentized range" in connection with an analysis of variance. Euphytica 1 (1952): 112-122.

6. Neumann, D., Uber die Variabilität der Wuchsleistung von Obstgehölzen in der Baumschule. Der Züchter 25 (1955): 140-153.

7. SMEETS, L., Some effects of the photoperiod on the shoot growth of cherry seedlings. Euphytica 5 (1956): 238-244.

8. WENT, F. W., Plant growth under controlled conditions. V. The relation between age, light, variety and thermoperiodicity of tomatoes. Amer. Journ. Bot. 32 (1945): 469-479. 